Supporting Information (15 pages)

\title{
Effects of Post-pyrolysis Air Oxidation of Biomass Chars on Adsorption of Neutral and lonizable Compounds
}

\author{
Feng Xiao ${ }^{\dagger, \ddagger}$, and Joseph J. Pignatello*,‡ \\ ${ }^{\dagger}$ Department of Civil Engineering, University of North Dakota, Grand Forks, North Dakota \\ 58202-8115, United States \\ ${ }^{\ddagger}$ Department of Environmental Sciences, The Connecticut Agricultural Experimental Station, \\ New Haven, Connecticut 06504-1106, United States
}

\section{Contents}

Methods supplement (Page S2)

Instrumental analysis and quality control (Page S3)

The value of $A$ in the relationship between surface electrical potential and electrokinetic (zeta) potential (Page S3)

Table (Pages S4 and S5)

o Table S1a. The values of Freundlich fitting parameters $\left(K_{\mathrm{F}}\right.$ and $\left.n\right)$ for adsorption of organic compounds on original and PPAO-treated chars. (Page S4)

o Table S1b. The values of Langmuir fitting parameters $\left(S_{\mathrm{LM}}\right.$ and $\left.K_{\mathrm{L}}\right)$ of the adsorption of organic compounds on original and PPAO-treated chars. (Page S5)

Figures (Page S6-Page S14)

o Figure S1. Adsorption of four amines $\left(\mathrm{p} K_{\mathrm{a}}=4-5\right)$ on original and 5-40 min PPAO-treated chars. (Page S6)

- Figure S2. Adsorption of neutral compounds on original and PPAO-treated chars. (Page S6)

o Figure S3. Potentiometric titration of original and PPAO-treated maple chars. (Page S7)

o Figures S4-S6. SEM-EDX image of CM0, CM20, and CM30 char particles. (Page S8-S10)

o Figure S7. Char mass volatized during PPAO for different initial char weights. (Page S11)

o Figure S8. SEM images of original and PPAO-treated CM char particles. (Page S12)

o Figure S9. Van Krevlin diagram of maple wood char (CM) as a function of PPAO duration (0-40 $\mathrm{min}$ ) where $\mathrm{H} / \mathrm{C}$ and $\mathrm{O} / \mathrm{C}$ are atomic ratios. (Page S13)

o Figure S10. Weight-based and surface area-based adsorption of three organic acids and one neutral compound on chars. (Page S13)

o Figure S11. Weight-normalized adsorption isotherms of prometon, 2,4-D and atrazine on original chars and chars receiving 30-min PPAO. (Page S14)

o Figure S12. Adsorption isotherms of 2,4-D on original and PPAO-treated maple wood char (CM). (Page S14)

References (Page S15) 


\section{Methods supplement}

Maple wood char $(\mathrm{CM})$ was prepared by heating shavings in a flow of $\mathrm{N}_{2}(1.5 \mathrm{~L} / \mathrm{min})$, first to 100 ${ }^{\circ} \mathrm{C}$ for $1 \mathrm{~h}$ to drive off moisture and then at $25{ }^{\circ} \mathrm{C} / \mathrm{min}$ to a final temperature of $400{ }^{\circ} \mathrm{C}$, which was held for $2 \mathrm{~h} .{ }^{1}$ The product was gently ground and then sieved (150- $\mu \mathrm{m}$ screen). It contained $74.8 \%$ $\mathrm{C}, 4.0 \% \mathrm{H}, 18.6 \% \mathrm{O},<0.5 \% \mathrm{~N}$, and $1.7 \%$ ash. Solid-state nuclear magnetic resonance spectrometry indicates $\mathrm{CM}$ is predominantly aromatic with mean minimum fused ring cluster size of 18 carbons. ${ }^{1}$ Pecan shell char (CP) was obtained from the U.S. Department of Agriculture, Agricultural Research Service where it was made anoxically at $400{ }^{\circ} \mathrm{C}$. It is granular in texture and contained $68.4 \% \mathrm{C}, 4.4 \% \mathrm{H}, 12.6 \% \mathrm{O},<0.5 \% \mathrm{~N}$, and $3.1 \%$ ash.

Pore size distribution (PSD), pore volume, and surface area (SA) were determined from the nitrogen $(77 \mathrm{~K})$ and carbon dioxide $(273 \mathrm{~K})$ adsorption isotherms after outgassing at $493 \mathrm{~K}^{2,3}$ Analysis of the high-resolution $\mathrm{N}_{2}$ adsorption isotherm $\left(p / p^{0}=10^{-6}-1\right)$ using nonlocal density functional theory (DFT) and assuming slit-shaped pores with graphitic walls generated the pore size distribution in the range 15-60 $\AA$ (mainly within the mesopore range). Analysis of the $\mathrm{CO}_{2}$ isotherm $\left(p / p^{0}=10^{-5}-0.029\right)$ using DFT and Monte Carlo methods yielded pore surface area and pore size distribution up to $14.7 \AA$ (within the micropore range). Nitrogen SA was calculated by the Brunauer-Emmett-Teller (BET) equation for 11 data between 0.05 and $0.3 p / p^{0}$. The carboxyl and hydroxyl contents were determined by potentiometric titration under $\mathrm{N}_{2}{ }^{4}$ Carboxyl content was calculated from the change in charge density (meq/g char) between $\mathrm{pH} 3$ and $8 .{ }^{4}$ Phenolic content was calculated from twice the change in charge density between $\mathrm{pH} 8$ and $10 .{ }^{4}$ Elemental analyses were performed by Galbraith Laboratories (Knoxville, TN). Images and $\mathrm{C}$ and $\mathrm{O}$ mapping were taken on a Hitachi SU8010 field-emission scanning electron microscope (SEM), coupled with an Oxford X-Max energy-dispersive X-ray spectrometer (EDX).

Adsorption isotherms were fit to the Freundlich and Langmuir models:

$$
\begin{aligned}
& C_{\mathrm{s}}=K_{\mathrm{F}} C_{\mathrm{w}}{ }^{n} \\
& C_{\mathrm{s}}=\frac{S_{\mathrm{LM}} K_{\mathrm{L}} C_{\mathrm{w}}}{1+K_{\mathrm{L}} C_{\mathrm{w}}}
\end{aligned}
$$

where $C_{\mathrm{s}}(\mathrm{mg} / \mathrm{kg})$ and $C_{\mathrm{w}}(\mathrm{mg} / \mathrm{L})$ are the adsorbed and dissolved concentrations, respectively. The Freundlich linearity index $n$ and capacity/affinity coefficient $K_{\mathrm{F}}\left(\mathrm{mg}^{1-\mathrm{n}} \mathrm{L}^{\mathrm{n}} \mathrm{kg}^{-1}\right)$ were obtained by linear regression according to the log-transformed form of eq 1 of data weighted by the dependent variable. The Langmuir maximum capacity $S_{\mathrm{LM}}(\mathrm{mg} / \mathrm{kg})$ and affinity $K_{\mathrm{L}}(\mathrm{L} / \mathrm{mg})$ coefficients were obtained by nonlinear regression of data weighted by the dependent variable. 


\section{Instrumental analysis and quality control}

The mobile phase of HPLC consisted of eluent A (water buffered at $\mathrm{pH} 3$ with $25 \times 10^{-3} \mathrm{~mol} / \mathrm{L}$ phosphate), and eluent B (HPLC-grade methanol). A gradient flow was employed to analyze pyridine: the A/B ratio changed from $95 / 5(\mathrm{v} / \mathrm{v})$ to $87.5 / 12.5$ during the first $2.5 \mathrm{~min}$, and then changed back to the ratio of $95 / 5$ at time $3.5 \mathrm{~min}$. An isocratic flow was employed to analyze the other compounds, using an $\mathrm{A} / \mathrm{B}$ ratio of 50/50 for quinoline, 60/40 for the mixture of 2,4-D and PTA or 2,4-D and 4-toluic acid, 70/30 for azinphos-methyl, MBPh, PTA, and 4-toluic acid, 75/25 for tebuthiuron and tebuthiuron, and $80 / 20$ for 2,4-D and the other compounds. The analytical column was an Eclipse Plus C18 $\left(150 \times 4.6 \mathrm{~mm}^{2}, 5 \mu \mathrm{m}\right.$, Agilent); the injection volume was 50 $\mu \mathrm{L}$; the flow rate was $1.0 \mathrm{~mL} / \mathrm{min}$; and the operating temperature was $25^{\circ} \mathrm{C}$. Concentrations were determined by detection at $254 \mathrm{~nm}$ for naphthalene, $256 \mathrm{~nm}$ for pyridine, and $228 \mathrm{~nm}$ for the others.

Blanks without adsorbent were run to assess adsorption to vials, which was found to be negligible. Likewise, adsorption to microfilters was negligible. Instrumental blanks were run to ensure freedom of contamination. All the samples were stored in tightly sealed vials and the concentrations of organic compounds were determined within two days using external standards. Standards curves were constructed with at least six standards spanning the range of solute concentration. In most situations stock solutions were prepared fresh for each experiment and assayed along with samples. In addition, no headspace was left in the adsorption tubes to minimize volatilization.

\section{The value of $A$ in the relationship between surface electrical potential ( $\Psi)$ and electrokinetic (zeta) potential $(\zeta)$}

For silicon nitride $\left(\mathrm{pH}_{\mathrm{pzc}}=3\right)$, Bousse et al. ${ }^{5}$ compared zeta potential with surface potential measured with light-addressable potentiometric sensors and found $A$ to be $\sim 10$ at $\mathrm{pH} 7$. For amphoteric aluminum oxide $\left(\left[\mathrm{Na}^{+}\right]=10^{-2}-10^{-3} \mathrm{M}, \mathrm{pH} 5.75-6.25\right)$, Zhang et al. ${ }^{6}$ using a co-ion $\left(\mathrm{Na}^{+}\right)$negative adsorption method found that $A$ ranged from $\sim 1$ to $\sim 2$. For various montmorillonites at $\mathrm{pH} \mathrm{7,} \mathrm{Li}$ and co-workers found by measuring basic cation concentrations in the diffuse double layer that $A$ ranged from $\sim 3$ to $\sim 6{ }^{7,8}$ Values are available for some organic materials but only by comparing zeta potentials with theoretical surface potentials: phosphoinositide membranes gave $A=\sim 1.8$ at $\mathrm{pH} 7.4$ and $0.1 \mathrm{M} \mathrm{NaCl}^{9}$; and solid lipid nanoparticles made from cacao butter and stearic acid gave $A=2.1-2.5$ at $\mathrm{pH} 7 .^{10}$ 


\begin{tabular}{|c|c|c|c|}
\hline \multicolumn{4}{|c|}{$\begin{array}{l}\text { Table S1a. The values of Freundlich fitting parameters }\left(K_{F} \text { and } n\right) \text { for } \\
\text { adsorption of organic compounds on original and PPAO-treated chars and a } \\
\text { commercial activated carbon (Filtrasorb 200). }\end{array}$} \\
\hline Compound & $K_{\mathrm{F}}\left(\mathrm{mg}^{1-\mathrm{n}} \mathbf{L}^{\mathrm{n}} \mathbf{k g}^{-1}\right)$ & $n$ & $C_{\mathrm{w}}(\mathrm{mg} / \mathrm{L})$ \\
\hline Prometon $(\mathrm{CP} 0)$ & $60 \pm 3^{\mathrm{b}}$ & $0.40 \pm 0.02$ & $0.9-21.0$ \\
\hline Prometon (CP30) & $310 \pm 24$ & $0.40 \pm 0.04$ & $0.3-14.8$ \\
\hline Prometon (CM0) & $320 \pm 40$ & $0.79 \pm 0.04$ & $0.1-55.6$ \\
\hline Prometon (CM30) & $5390 \pm 490$ & $0.40 \pm 0.02$ & $0.05-62.3$ \\
\hline $\begin{array}{c}\text { Terbutryn } \\
\text { (CM0) }\end{array}$ & $3240 \pm 230$ & $0.22 \pm 0.03$ & $0.1-19.1$ \\
\hline $\begin{array}{l}\text { Terbutryn } \\
\text { (CM30) }\end{array}$ & $7460 \pm 480$ & $0.52 \pm 0.02$ & $0.6-23.4$ \\
\hline $\begin{array}{l}\text { Atrazine } \\
\text { (CM0) }\end{array}$ & $200 \pm 80$ & $1.01 \pm 0.15$ & $0.8-15.5$ \\
\hline $\begin{array}{l}\text { Atrazine } \\
\text { (CM30) }\end{array}$ & $80 \pm 70$ & $1.97 \pm 0.31$ & $2.5-20.5$ \\
\hline $\begin{array}{l}2,4-\mathrm{D} \\
(\mathrm{CM} 0)\end{array}$ & $120 \pm 20$ & $0.66 \pm 0.05$ & $0.8-34.5$ \\
\hline $\begin{array}{l}2,4-\mathrm{D} \\
\text { (CM5) }\end{array}$ & $240 \pm 20$ & $0.78 \pm 0.02$ & $0.6-39.4$ \\
\hline $\begin{array}{c}2,4-\mathrm{D} \\
\text { (CM10) }\end{array}$ & $460 \pm 30$ & $0.78 \pm 0.02$ & $0.7-36.4$ \\
\hline $\begin{array}{l}2,4-\mathrm{D} \\
(\mathrm{CM} 20)\end{array}$ & $1370 \pm 60$ & $0.60 \pm 0.03$ & $0.4-40.5$ \\
\hline $\begin{array}{c}2,4-\mathrm{D} \\
(\mathrm{CM} 30)\end{array}$ & $2390 \pm 120$ & $0.54 \pm 0.02$ & $0.5-39.6$ \\
\hline $\begin{array}{c}2,4-\mathrm{D} \\
(\mathrm{CM} 40) \\
\end{array}$ & $3230 \pm 240$ & $0.46 \pm 0.03$ & $0.4-36.6$ \\
\hline $\begin{array}{c}2,4-\mathrm{D} \\
\text { (Filtrasorb 200) }\end{array}$ & $4090 \pm 394$ & $0.76 \pm 0.05$ & $0.4-9.4$ \\
\hline
\end{tabular}




\begin{tabular}{|c|c|c|c|}
\hline \multicolumn{4}{|c|}{$\begin{array}{l}\text { Table S1b. The values of Langmuir fitting parameters }\left(S_{\mathrm{LM}} \text { and } K_{\mathrm{L}}\right) \text { of the } \\
\text { adsorption of organic compounds on original and PPAO-treated chars and a } \\
\text { commercial activated carbon (Filtrasorb 200). }\end{array}$} \\
\hline Compound & $S_{L M}(\mathbf{m g} / \mathbf{k g})$ & $K_{\mathrm{L}}(\mathrm{L} / \mathrm{mg})$ & $C_{\mathrm{w}}(\mathrm{mg} / \mathrm{L})$ \\
\hline Prometon $(\mathrm{CP} 0)$ & $240 \pm 20^{\mathrm{b}}$ & $0.20 \pm 0.05$ & $0.9-21.0$ \\
\hline Prometon $(\mathrm{CP} 30)$ & $960 \pm 30$ & $0.40 \pm 0.04$ & $0.3-14.8$ \\
\hline Prometon (CM0) & $12910 \pm 1650$ & $0.02 \pm 0.004$ & $0.1-55.6$ \\
\hline Prometon (CM30) & $33850 \pm 2510$ & $0.07 \pm 0.02$ & $0.05-62.3$ \\
\hline $\begin{array}{c}\text { Terbutryn } \\
\text { (CM0) }\end{array}$ & $5770 \pm 220$ & $1.74 \pm 0.29$ & $0.11-19.1$ \\
\hline $\begin{array}{l}\text { Terbutryn } \\
\text { (CM30) }\end{array}$ & $56900 \pm 5730$ & $0.08 \pm 0.02$ & $0.6-23.4$ \\
\hline $\begin{array}{l}\text { Atrazine } \\
(\mathrm{CM} 0)\end{array}$ & - & - & $0.75-15.5$ \\
\hline $\begin{array}{l}\text { Atrazine } \\
(\mathrm{CM} 30)\end{array}$ & - & - & $2.5-20.5$ \\
\hline $\begin{array}{l}2,4-\mathrm{D} \\
(\mathrm{CM} 0)\end{array}$ & $1830 \pm 170$ & $0.06 \pm 0.01$ & $0.8-34.5$ \\
\hline $\begin{array}{l}2,4-\mathrm{D} \\
\text { (CM5) }\end{array}$ & $6200 \pm 430$ & $0.03 \pm 0.004$ & $0.6-39.4$ \\
\hline $\begin{array}{l}2,4-\mathrm{D} \\
(\mathrm{CM} 10)\end{array}$ & $11870 \pm 950$ & $0.03 \pm 0.004$ & $0.7-36.4$ \\
\hline $\begin{array}{l}2,4-\mathrm{D} \\
(\mathrm{CM} 20) \\
\end{array}$ & $22520 \pm 1400$ & $0.03 \pm 0.004$ & $0.4-40.5$ \\
\hline $\begin{array}{l}2,4-\mathrm{D} \\
(\mathrm{CM} 30)\end{array}$ & $24670 \pm 1130$ & $0.05 \pm 0.005$ & $0.5-39.6$ \\
\hline $\begin{array}{l}2,4-\mathrm{D} \\
(\mathrm{CM} 40)\end{array}$ & $29190 \pm 1500$ & $0.05 \pm 0.006$ & $0.4-36.6$ \\
\hline $\begin{array}{c}2,4-\mathrm{D} \\
(\text { Filtrasorb 200) }\end{array}$ & $54370 \pm 9480$ & $0.07 \pm 0.02$ & $0.4-9.4$ \\
\hline \multicolumn{4}{|c|}{$\begin{array}{l}{ }^{a} C_{\mathrm{w}} \text { : equilibrium concentrations for constructing the adsorption isotherms; CP: char } \\
\text { from pecan shell; CM: char from maple wood. The adsorption isotherms for atrazine } \\
\text { could not be fit to the Langmuir model because they are convex to the } \mathrm{x} \text { axis. } \\
\text { b standard error of the mean. }\end{array}$} \\
\hline
\end{tabular}



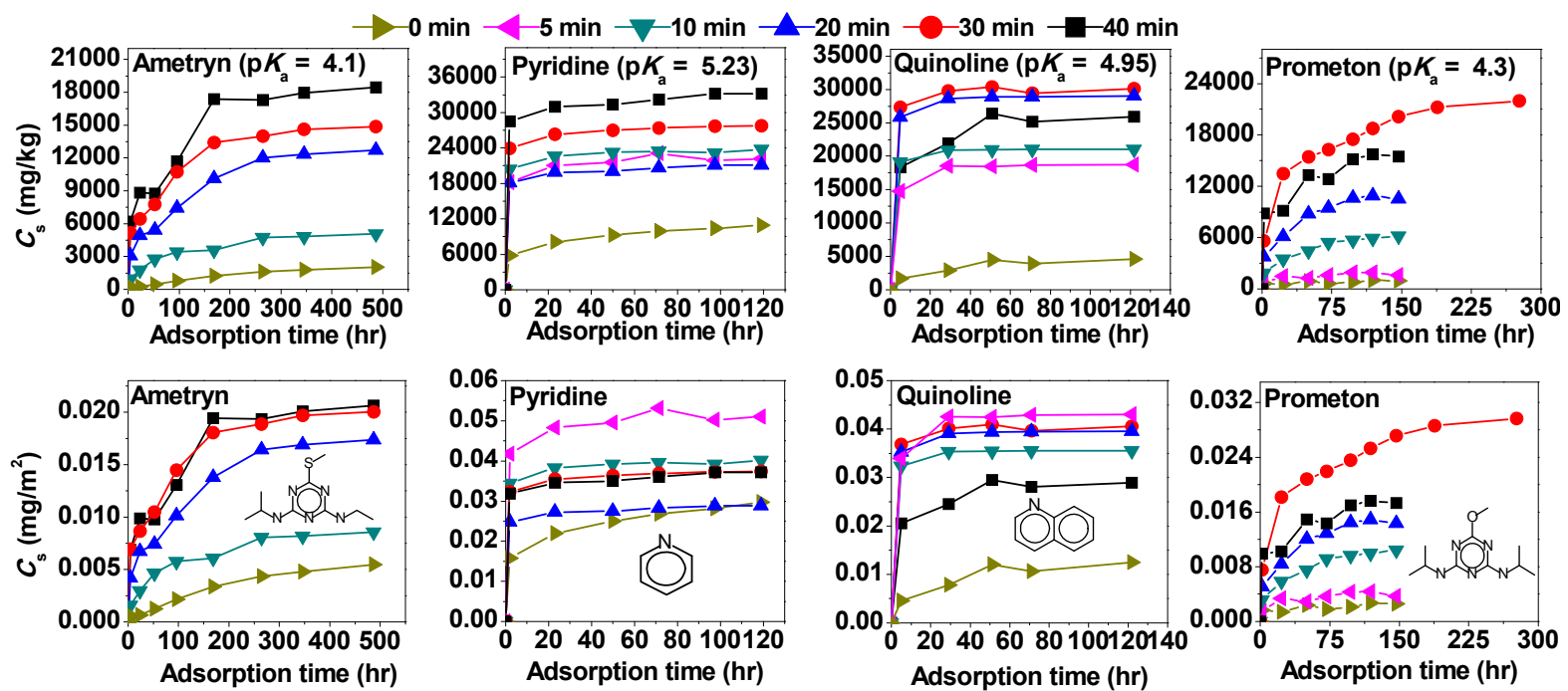

Figure S1. Adsorption of four amines $\left(\mathrm{p} K_{\mathrm{a}}=4-5\right)$ at $\mathrm{pH} \sim 7.4$ on original and 5-40 min PPAOtreated maple wood chars (CM). Initial concentration: ametryne, 12; pyridine, 39; quinoline, 15; prometon, $15 \mathrm{mg} / \mathrm{L}$. Top row figures: weight normalized $C_{\mathrm{s}}$; bottom row figures: $\mathrm{CO}_{2}-\mathrm{SA}$ normalized $C_{\mathrm{s}}$. (Note that uptake by $\mathrm{CM} 0$ was faster than we previously reported ${ }^{11}$ because here we used smaller-sized char $(<150 \mu \mathrm{m})$ compared to the previous study $(<500 \mu \mathrm{m})){ }^{11}$
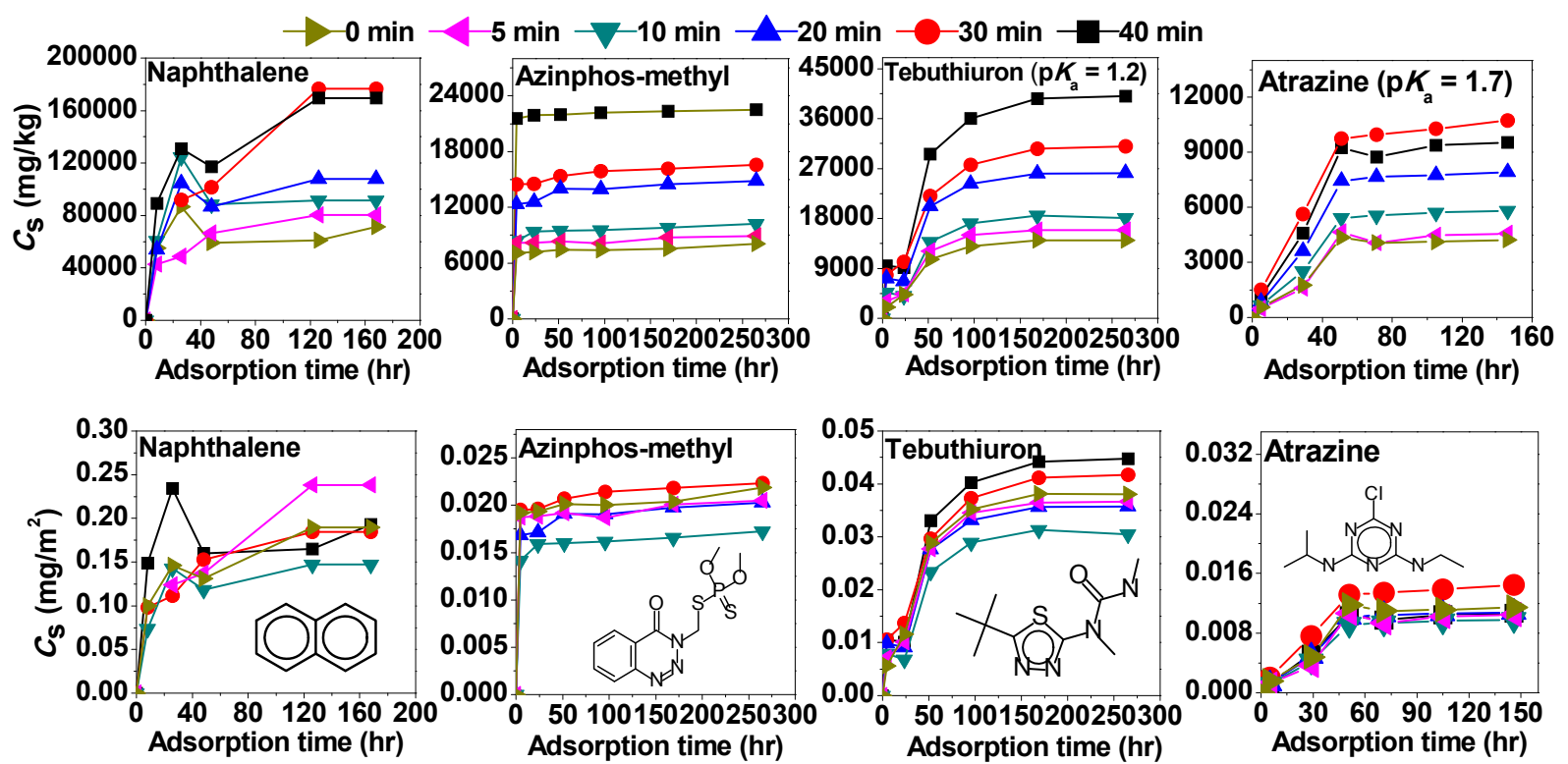

Figure S2. Adsorption of neutral compounds at $\mathrm{pH} \sim 7.4$ on original and PPAO-treated maple wood chars $(\mathrm{CM})$. Initial concentrations $(\mathrm{mg} / \mathrm{L})$ : naphthalene, 10; azinphos-methyl, 8; tebuthiuron, 24; atrazine, 6 . Top row figures: weight-normalized $C_{\mathrm{s}}$; bottom row figures: $\mathrm{CO}_{2}$ micropore-SA normalized $C_{\mathrm{s}}$. (Note that uptake by $\mathrm{CM} 0$ was faster than we previously reported because here we used smaller-sized char $(<150 \mu \mathrm{m})$ compared to the previous study $(<500$ $\mu \mathrm{m}))^{11}$ 


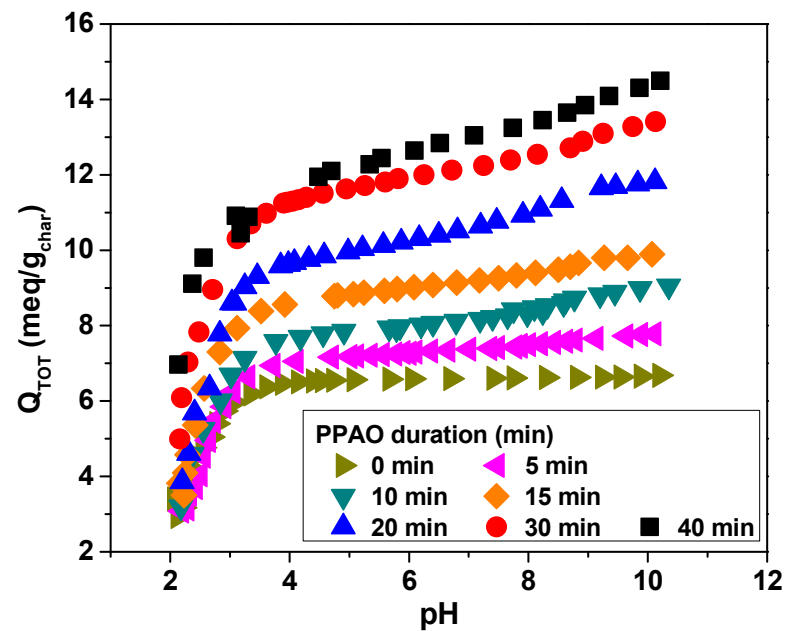

Figure S3. Potentiometric titration of original and PPAO-treated CM chars. 

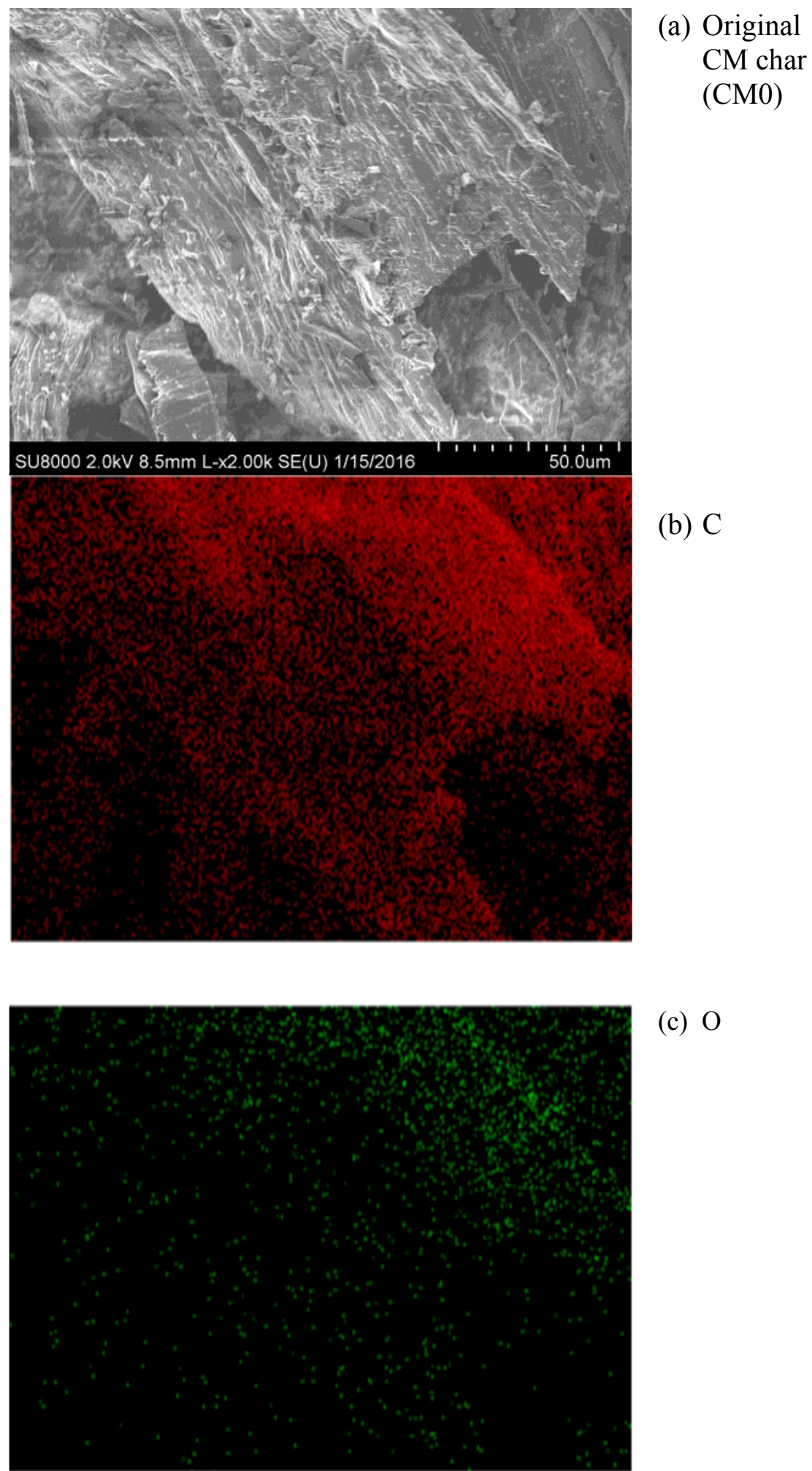

(c) $\mathrm{O}$

Figure S4. (a) SEM image of original char particles; (b) and (c) are EDS mapping of C and O, respectively. 


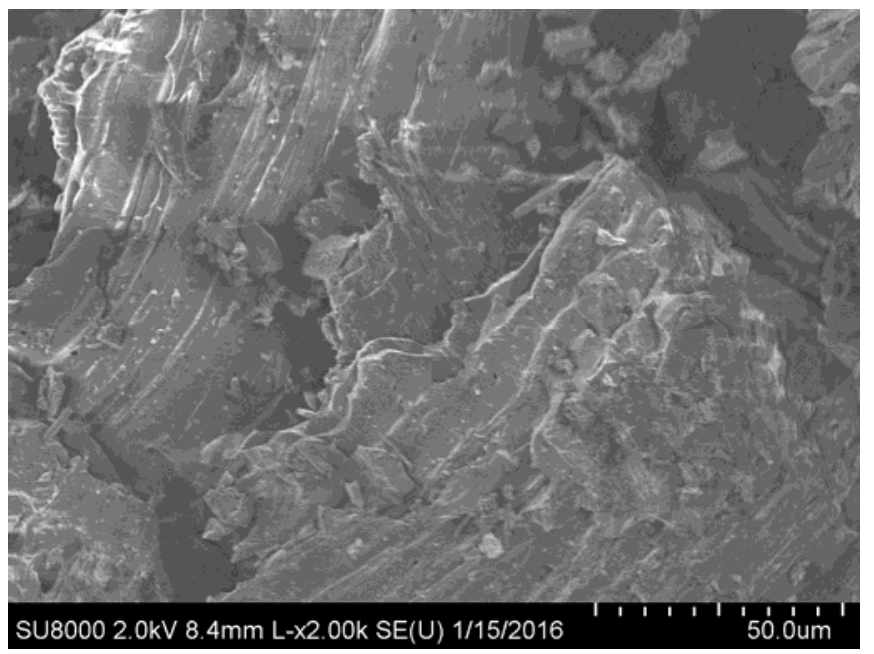

(a) CM20 Char

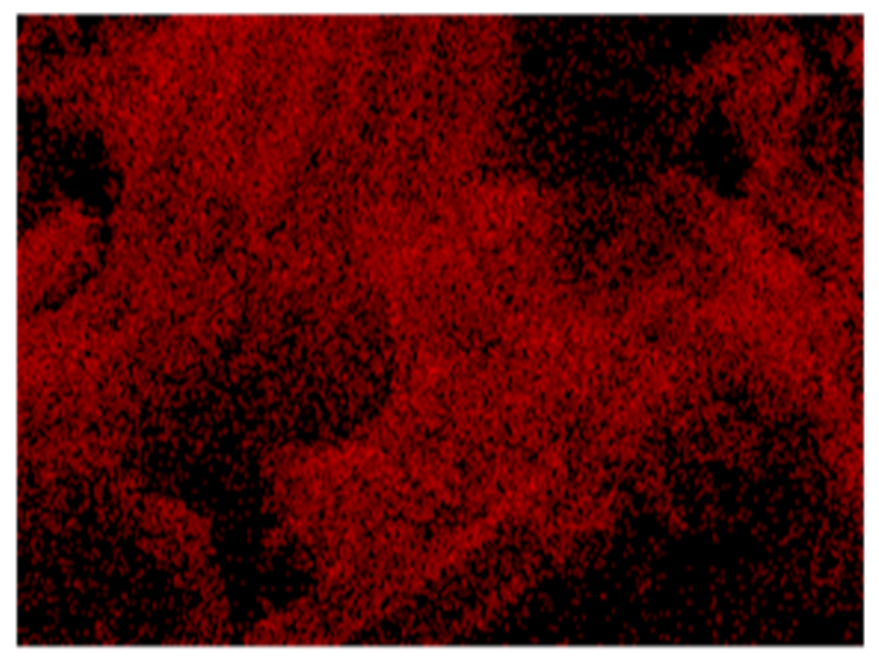

(b) $\mathrm{C}$

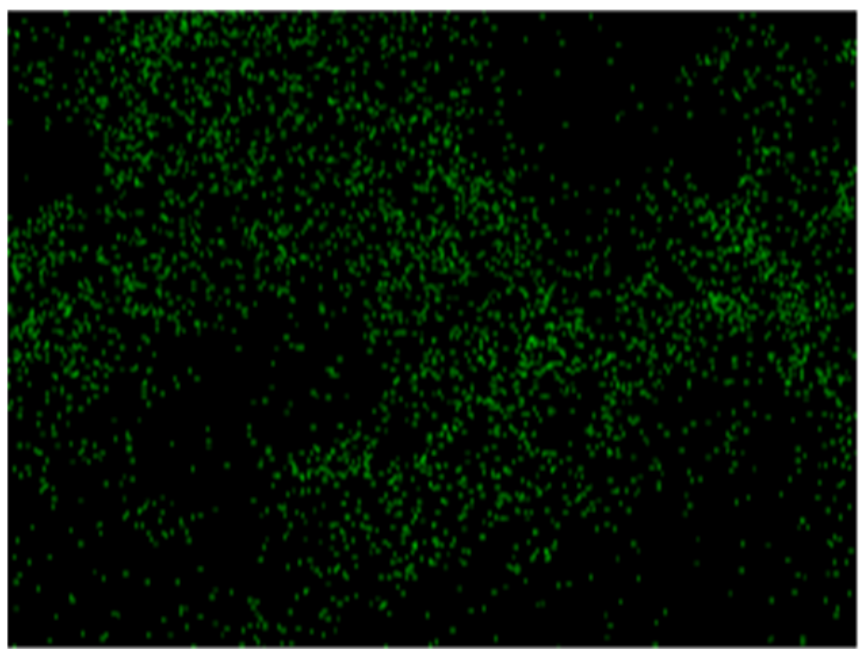

(c) $\mathrm{O}$

Figure S5. (a) SEM image of CM20 char particles; (b) and (c) are EDS mapping of C and O, respectively. 


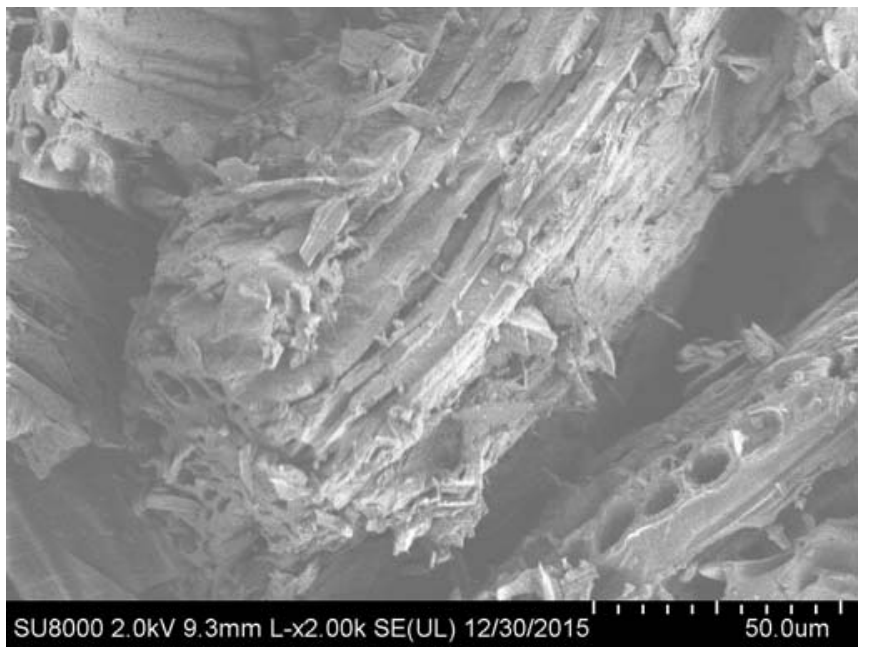

(a) CM30 Char

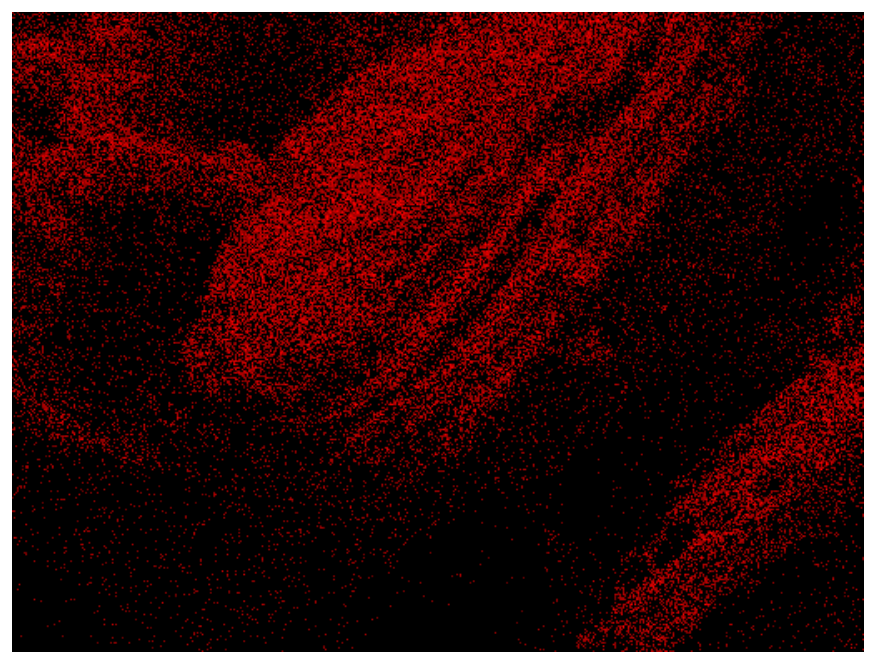

(b) $\mathrm{C}$

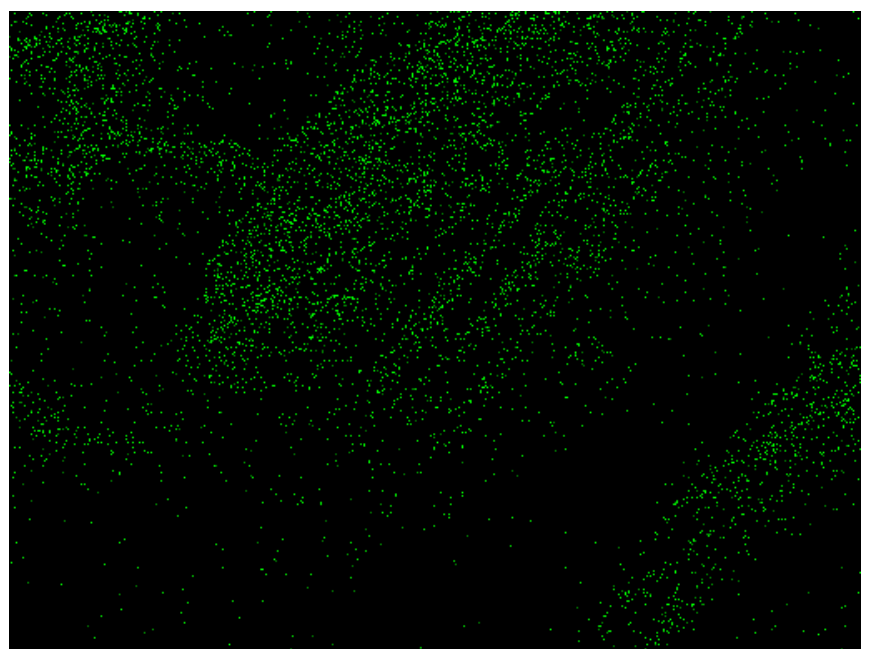

(c) $\mathrm{O}$

Figure S6. (a) SEM-EDS image of CM30 char particles (red: C; green: O); (b) and (c) are EDS mapping of $\mathrm{C}$ and $\mathrm{O}$, respectively. 


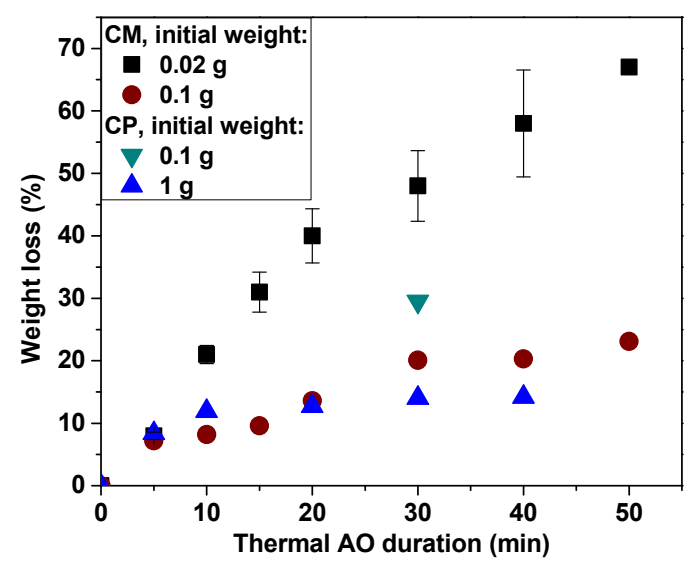

Figure S7. Char mass volatized during PPAO for different initial char weights. CP: char from pecan shell; CM: char from maple wood. 


\section{(a) Original CM (CMO)}

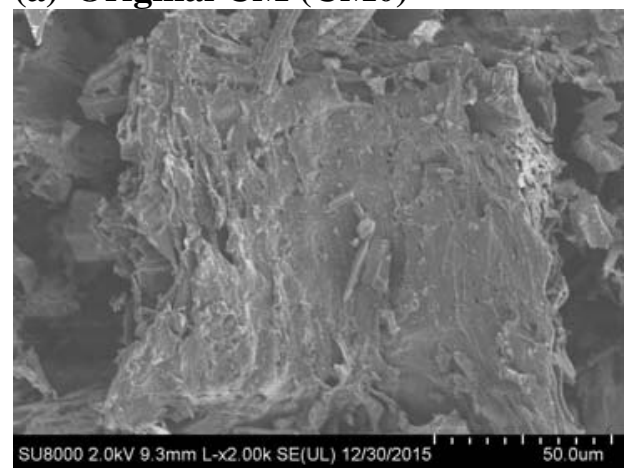

(c) 10-min PPAO-treated CM (CM10)

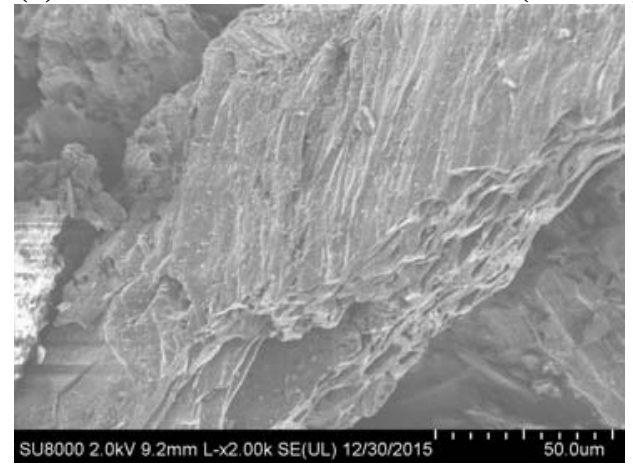

(e) 20-min PPAO-treated CM (CM30)

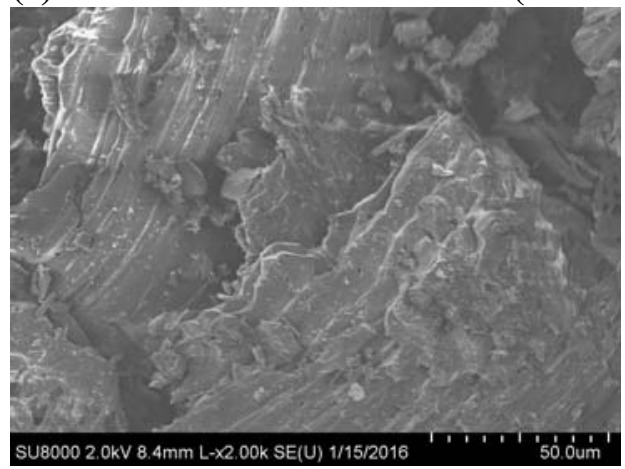

(g) 40-min PPAO-treated CM (CM40)

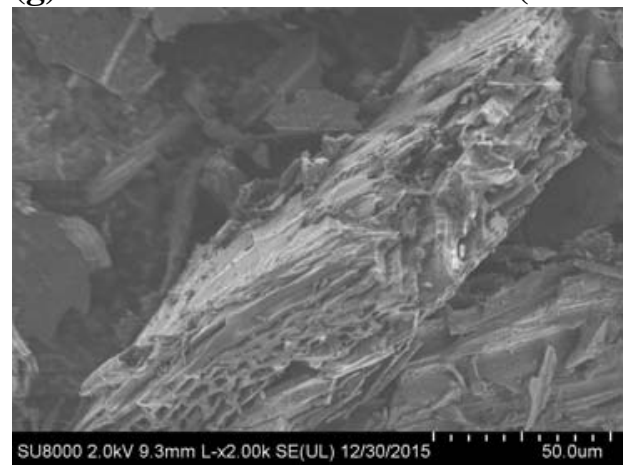

(b) Original CM (CM0)

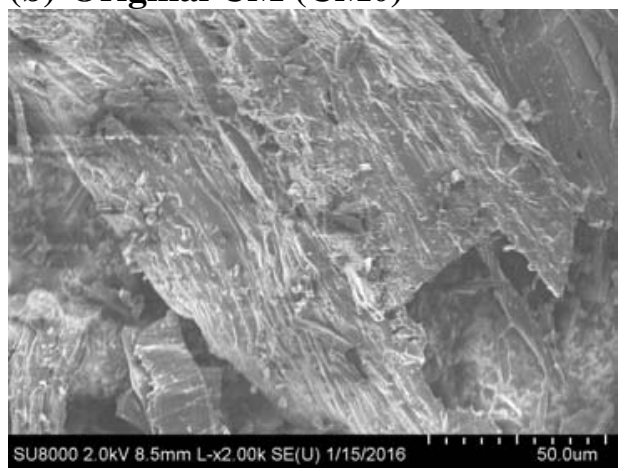

(d) 20-min PPAO-treated CM (CM20)

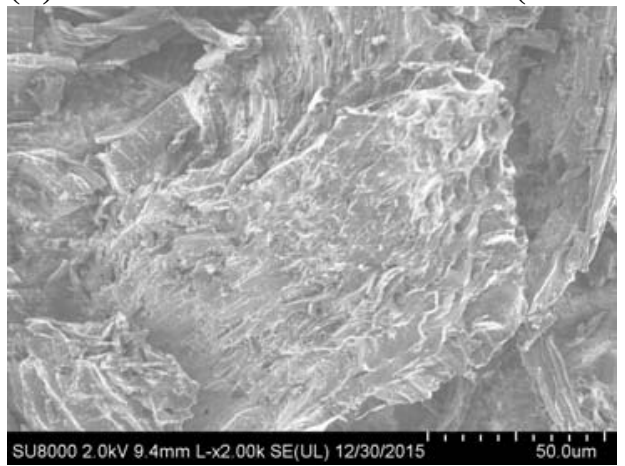

(f) 30-min PPAO-treated CM (CM30)

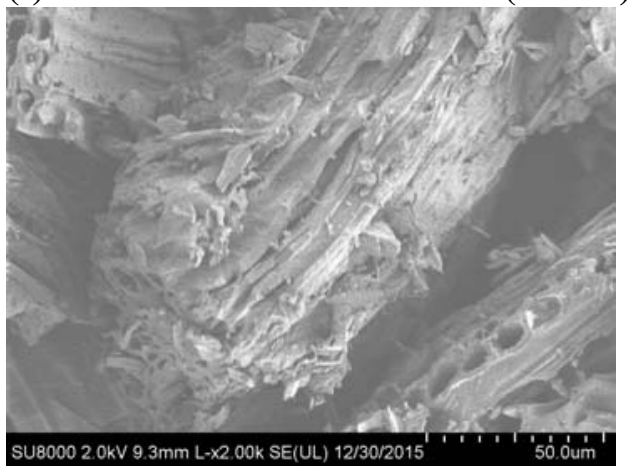

Figure S8. SEM images of original and PPAOtreated CM char particles. (a) and (b) Original CM char; (c)-(g): 10-40 min PPAOed CM chars. 


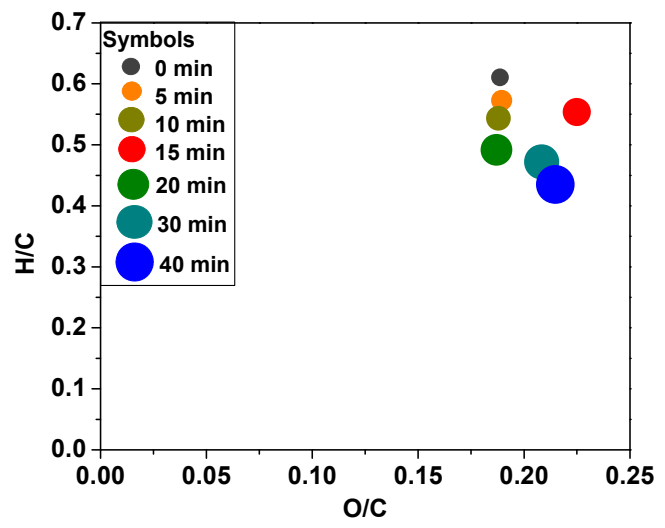

Figure S9. Van Krevlin diagram of maple wood char (CM) as a function of PPAO duration (0-40 $\mathrm{min}$ ) where $\mathrm{H} / \mathrm{C}$ and $\mathrm{O} / \mathrm{C}$ are atomic ratios. Symbol size is used only to distinguish the data points.

(a)
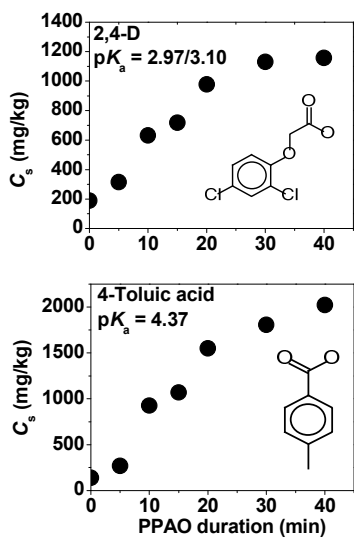
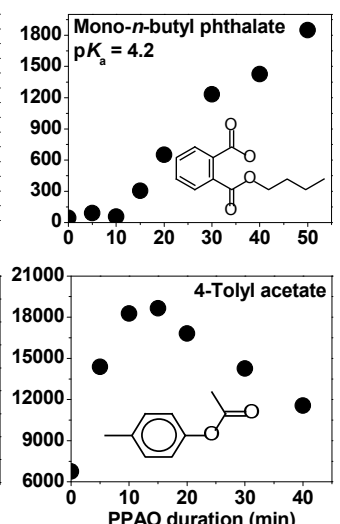

(b)
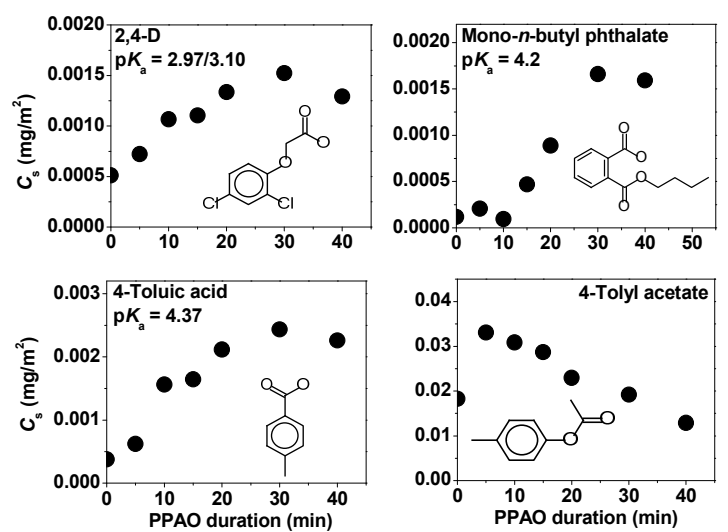

Figure S10. (a) Weight-normalized and (b) $\mathrm{CO}_{2}$ micropore SA-normalized adsorption of three organic acids and one neutral compound on maple wood char (CM) at $\mathrm{pH} \sim 7.4$ as a function of PPAO time (0-40 min). Initial concentration $(\mathrm{mg} / \mathrm{L})$ : 9.8 for 2,4-D and 8 for the other three compounds. 

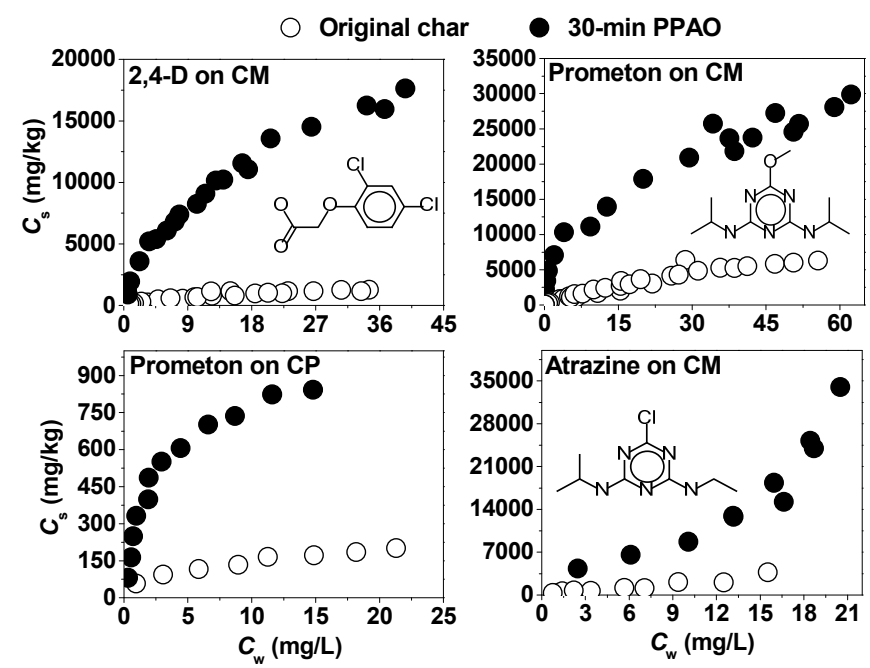

Figure S11. Weight-normalized adsorption isotherms of 2,4-D $\left(\mathrm{p} K_{\mathrm{a}}=2.97-3.10\right)$, atrazine $\left(\mathrm{p} K_{\mathrm{a}}=\right.$ 1.7), and prometon $\left(\mathrm{p} K_{\mathrm{a}}=4.3\right)$ on two original and PPAO-treated maple wood $(\mathrm{CM})$ and pecan shell (CP) chars ( $\mathrm{pH} \sim 7.4)$.

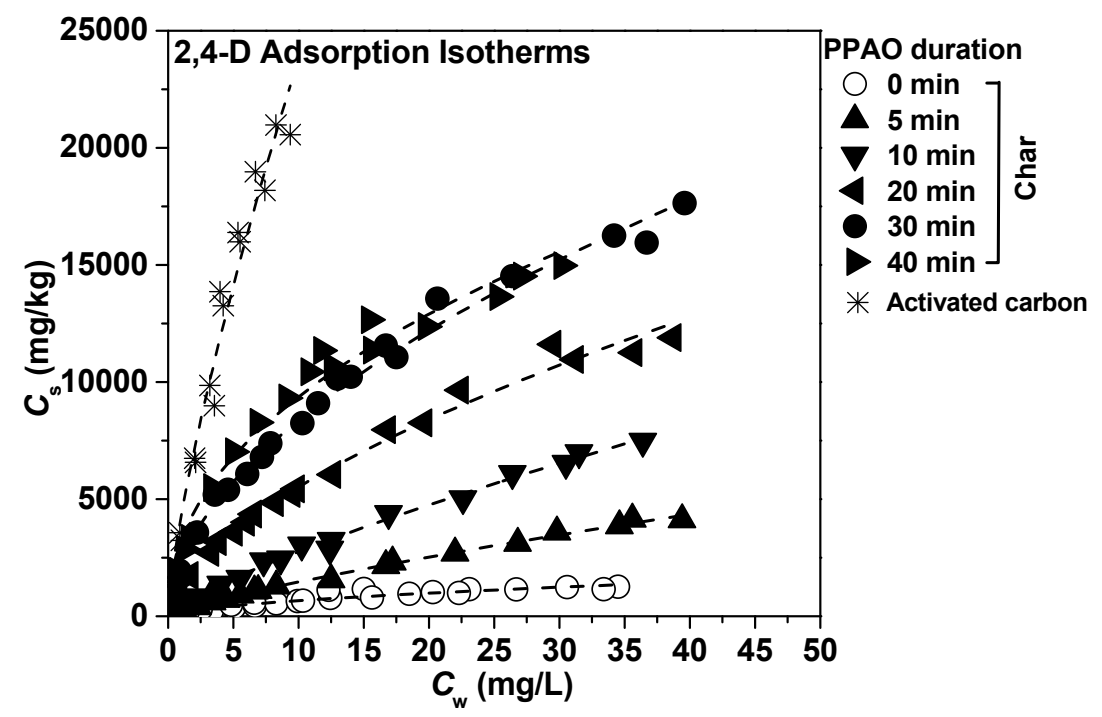

Figure S12. Adsorption isotherms of 2,4-D on original and PPAO-treated maple wood char (CM) and Calgon Filtrasorb 200 activated carbon. Lines represent Freundlich fit. 


\section{References of Supporting Information}

(1) Cao, X. Y.; Pignatello, J. J.; Li, Y.; Lattao, C.; Chappell, M. A.; Chen, N.; Miller, L. F.; Mao, J. D. Characterization of wood chars produced at different temperatures using advanced solid-state C-13 NMR spectroscopic techniques. Energ. Fuel. 2012, 26, 5983-5991.

(2) Kwon, S.; Pignatello, J. J. Effect of natural organic substances on the surface and adsorptive properties of environmental black carbon (char): pseudo pore blockage by model lipid components and its implications for N2-probed surface properties of natural sorbents. Environ. Sci. Technol. 2005, 39, 7932-7939.

(3) Braida, W. J.; Pignatello, J. J.; Lu, Y. F.; Ravikovitch, P. I.; Neimark, A. V.; Xing, B. S. Sorption hysteresis of benzene in charcoal particles. Environ. Sci. Technol. 2003, 37, 409-417.

(4) Ritchie, J. D.; Perdue, E. M. Proton-binding study of standard and reference fulvic acids, humic acids, and natural organic matter. Geochim. Cosmochim. Ac. 2003, 67, 85-96.

(5) Bousse, L. J.; Mostarshed, S.; Hafeman, D. Combined measurement of surfacepotential and zeta potential at insulator electrolyte interfaces. Sensors and Actuators B-Chemical. 1992, 10, 67-71.

(6) Zhang, Z. Z.; Sparks, D. L.; Scrivner, N. C. Characterization and modeling of the Al-oxide/aqueous solution interface: 1 . Measurement of electrostatic potential at the origin of the diffuse layer using aegative adsorption of Na+ ions. J. Colloid Interface Sci. 1994, 162, 244-251.

(7) Ding, W. Q.; Liu, X. M.; Song, L.; Li, Q.; Zhu, Q. H.; Zhu, H. L.; Hu, F. N.; Luo, Y. X.; Zhu, L. H.; Li, H. An approach to estimate the position of the shear plane for colloidal particles in an electrophoresis experiment. Surf. Sci. 2015, 632, 50-59.

(8) Hou, J.; Li, H.; Zhu, H. L.; Wu, L. S. Determination of clay surface potential: A more reliable approach. Soil Sci. Soc. Am. J. 2009, 73, 1658-1663.

(9) Ohki, S.; Muller, M.; Arnold, K.; Ohshima, H. Surface potential of phosphoinositide membranes: Comparison between theory and experiment. Colloids and Surfaces B-Biointerfaces. 2010, 79, 210-218.

(10) Kuo, Y. C.; Chen, I. C. Evaluation of surface charge density and surface potential by electrophoretic mobility for solid lipid nanoparticles and human brain-microvascular endothelial cells. J. Phys. Chem. B. 2007, 111, 11228-11236.

(11) Xiao, F.; Pignatello, J. J. Interactions of triazine herbicides with biochar: Steric and electronic effects. Water Res. 2015, 80, 179-188. 